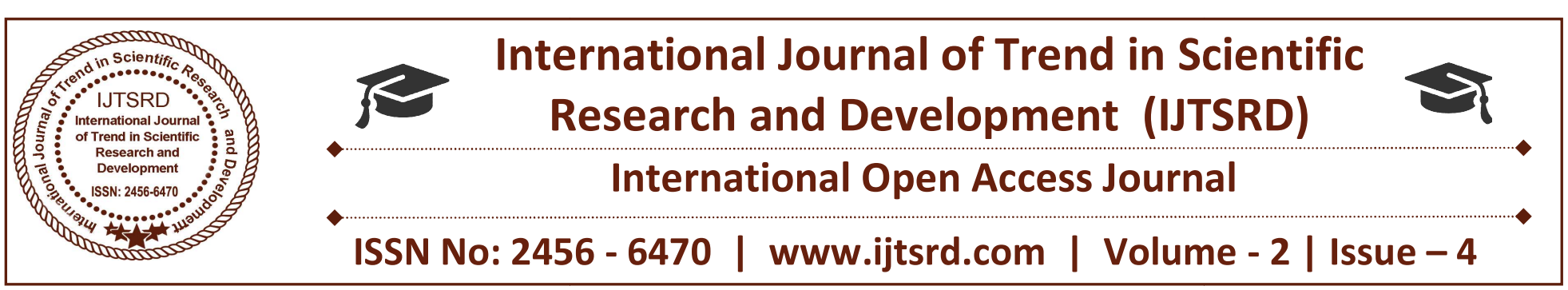

\title{
Economic Analysis of Machine Transplanted Rice in Thoothukudi District
}

\author{
Dr. T. Rajendran ${ }^{1}$, R. Kavitha ${ }^{2}$, S. P. PrasathBalaji ${ }^{2}$, A. Mathivanan ${ }^{2}$ \\ ${ }^{1}$ Assistant Professor [Agrl. Economics], ${ }^{2}$ B. Sc [Agricultural] Students \\ Tamil Nadu Agricultural University, Department of Social Sciences, \\ Agricultural College and Research Institute, Killikulam, Vallanad, Tamil Nadu, India
}

\begin{abstract}
Rice is being cultivated in conventional method of transplanting, but due to shortage of water and labor, new technique called Machine Transplanting is practiced by few farmers nowadays. Machine transplanting involves planting young rice seedlings into puddled soil by a machine. It requires considerably less time and labor than manual transplanting. Thoothukudi district is one among the major producers of rice in Tamil Nadu. This is study is mainly focusing on to assess the economic analysis of machine transplanted rice in Thoothukudi district.
\end{abstract}

Total cost of seedling for traditional method of planting seedlings per acre was Rs. 1800/- and machine transplanting was Rs. 1000/- per acre. The expenses incurred on plant protection was slightly high in case of conventionally planted fields [Rs. $1500 /-]$, as compared to the mechanically transplanted fields [Rs.1100/-]. Weed management was comparatively lesser [Rs. 3600/-] in case of mechanical transplanted fields, this is mainly because of practicing Cono weeder. But in case of conventionally planted fields weeding expenses reported on Rs. 4000/-. Regarding yield higher in machine transplanted rice $[2350 \mathrm{~kg} / \mathrm{ac}]$ when compared to conventional transplanted rice [2000 $\mathrm{kg} / \mathrm{ac}]$. The benefit-cost ratio was higher in machine transplanted rice [1:2.5] where is in conventional transplanted rice [1: 1.9]. Hence, the farmers might have more scope to cultivate machine transplanted rice with higher profitability. The constraints faced by the farmers in machine transplantation were no proper training on operation, Non-timely availability of transplanter and land fragmentation. If increase more training to the farmers to operate rice transplanter and

government might encourage more hiring centers for rice transplanter might boost up the machine transplanted rice.

Keywords: economics, rice, conventional planting, machine transplanter

\section{INTRODUCTION}

Tamil Nadu is rapidly transforming to high level of agricultural mechanization. Due to the sudden change in labour scenario, many farmers adopted mechanization in rice. Different custom hire operators have emerged according to the economic necessity especially for rice harvesting and transplanting in addition to the traditional services of ploughing and transport. However the small and medium farmers fund it extremely difficult to carry out day to day work. Due to the fragmented holding the farmers are not able to engage private hire operators. Rice is being cultivated in conventional method of transplanting, but due to shortage of water and labor, new technique called Machine Transplanting is practiced by few farmers nowadays. Machine transplanting involves planting young rice seedlings into puddled soil by a machine. It requires considerably less time and labor than manual transplanting. Thoothukudi district is one among the major producers of rice in Tamil Nadu

Farm mechanization has been helpful to bring about a significant improvement in agricultural productivity. Thus, there is strong need for mechanization of agricultural operations. The factors that justify the strengthening of farm mechanization in the country can be numerous. The timeliness of operations has assumed greater significance in obtaining optimal 
yields from different crops, which has been possible by way of mechanization. Hence, there is need to assess the economic analysis of machine transplanted rice in Thoothukudi district.

\section{Methodology}

Thoothukudi, district was selected purposively as it has an area of 1000 ha of Paddy in the district. It occupies pride place in area and production of the state and farmers of this district were practicing mechanization in almost all the rice farm operations. A multi-stage sampling technique was followed for the purpose of selection of primary sampling units. In Thoothukudi, district, two blocks was selected in randomly viz. Alwarthirunagari, and Srivaikundam. Then two villages were selected in randomly per block. Each village from 10 sample rice growers were selected in randomly. Thus total sampling size will leads to 40. Simple percentage analysis has been used to estimating costs and returns.

\section{Results and Discussions}

\section{Cost of Cultivation of Rice}

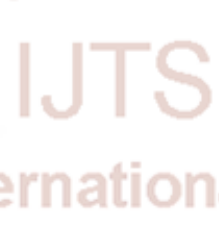

The cost of cultivation of rice under mechanical and conventional methods was analyzed and presented in the table 1 . It is concluded from the Table 1 that total cost of seedling for traditional method of planting seedlings were produced under conventional nursery in which cost of seedling per acre was Rs. 1800/- per acre. The cost of seedlings for machine transplanting was estimated to Rs. 1000/- per acre. The expenses incurred on plant protection was slightly high in case of conventionally planted fields [Rs. 1500/-], as compared to the mechanically transplanted fields [Rs.1100/-]. There was less incidence of pest and diseases in case of mechanical transplanted fields compared to the conventionally planted field, this mainly because of the perfect maintenance of ventilation due to proper spacing between plants and rows.

Expenses incurred on weed management was comparatively lesser [Rs. 3600/-] in case of mechanical transplanted fields, this is mainly because of practicing Cono-weeder. Farmers were reported that use of cono-weeder would increase the sprouting more tillers per hill through providing more aeration to the roots and also increase the nutrients uptake. But in case of conventionally planted fields weeding expenses reported on Rs. 4000/-. There would not be significant difference on expenses incurred on harvesting expenditures since all farmers were used combined harvester for harvesting of the crop. Regarding yield higher in machine transplanted rice [2350 $\mathrm{kg} / \mathrm{ac}]$ when compared to conventional transplanted rice $[2000 \mathrm{~kg} / \mathrm{ac}]$.

It could be seen from the table 2, the benefit-cost ratio was higher in machine transplanted rice [1:2.5] where is in conventional transplanted rice [1: 1.9]. Hence, the farmers might have more scope to cultivate machine transplanted rice with higher profitability. 
International Journal of Trend in Scientific Research and Development (IJTSRD) ISSN: 2456-6470

Table 1 Cost of Cultivation of Rice [Rs./acre]

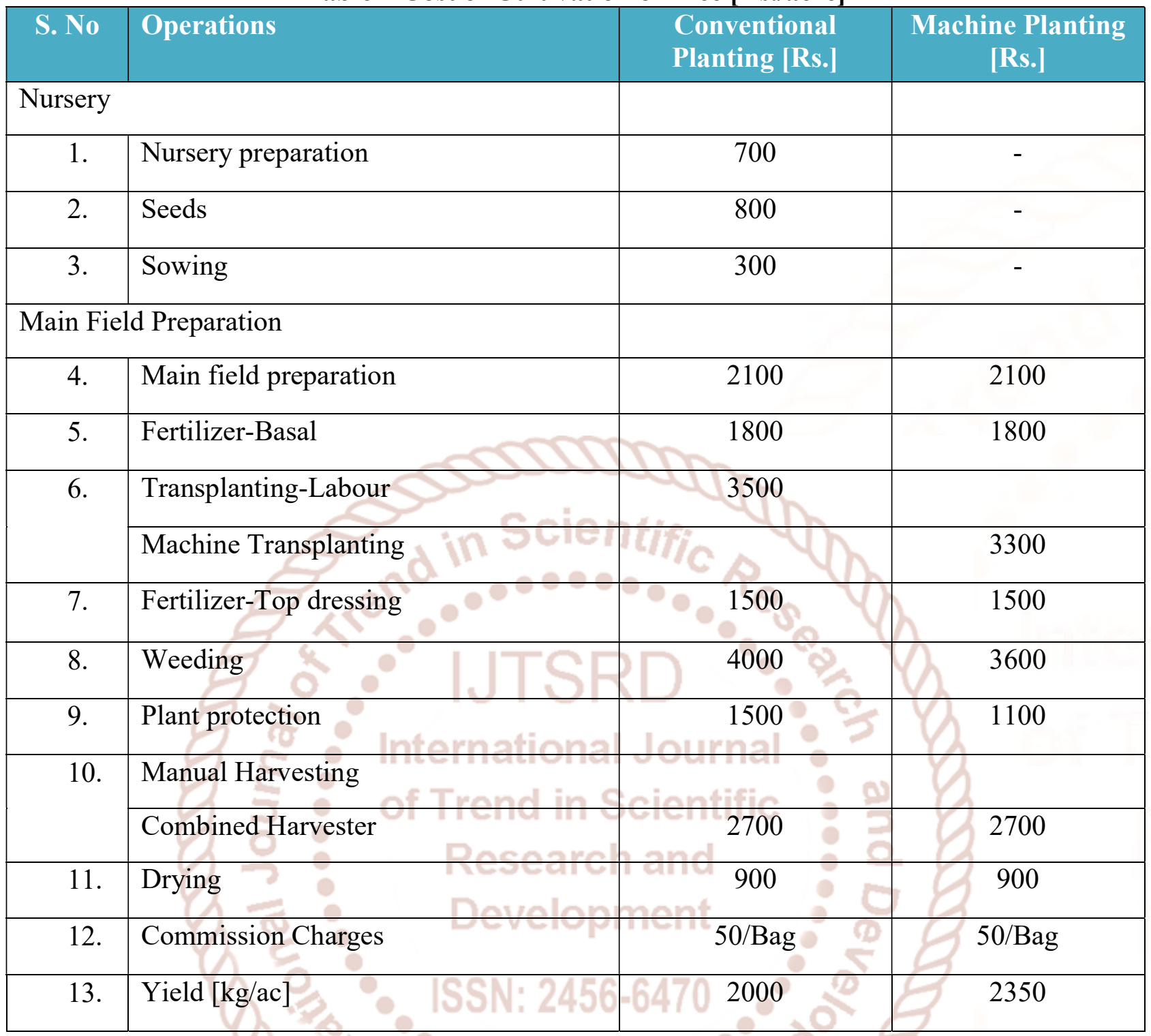

\section{Table 2 Benefit-Cost Ratio}

\begin{tabular}{|l|l|l|l|}
\hline S. No & \multicolumn{1}{|c|}{ Particulars } & \multicolumn{1}{|c|}{$\begin{array}{c}\text { Conventional } \\
\text { Planting }\end{array}$} & \multicolumn{1}{|c|}{$\begin{array}{c}\text { Mechanical } \\
\text { Planting }\end{array}$} \\
\hline 1 & Yield [productivity] in kgs & 2000 & 2350 \\
\hline 2 & Average Price [per kg] & Rs. $16.50 /-$ & Rs. $16.50 /-$ \\
\hline 3 & Cost of Cultivation [Rs. per acre] & Rs. 19800/- & Rs. 17000/- \\
\hline 4 & Returns from main product [Rs/ac] & Rs. 33000/- & Rs. 38775/- \\
\hline 5 & Returns from by product [Rs/ac] & Rs. 6000/- & Rs. 4500/- \\
\hline 6 & Gross return [per acre] & Rs. 39000/- & Rs. 43275/- \\
\hline 7 & Net return [per acre] & Rs. $19200 /-$ & Rs. 26275/- \\
\hline 8 & Benefit : Cost Ratio & $\mathbf{1 : 1 . 9}$ & $\mathbf{1 : 2 . 5}$ \\
\hline
\end{tabular}


Reason quoted by the farmers for adoption of machine transplantation were uniform sowing, Time saving, Reduction of labours. Lesser Pest and Disease incidence and higher profitability

Constraints faced by the farmers in machine transplantation were no proper training on operation, Non-timely availability of transplanter and Land fragmentation.

Suggestions given by the Farmers to overcome the constraints were Need more training to the farmers to operate rice transplanter, Government might encourage more hiring centers for rice transplanter and Need more subsidies on rice transplanter to the farmers.

Machine Transplanted Rice can be further increased by following the steps increase the subsidized transplanting machinery, Providing incentive to farmer for mechanized transplanting, More training for women SHGs to use transplanting machinery in order to ensure alternative employment opportunities, Setting up separate training center to train operators or initiating apprentice training under government subsidy and Ensuring only proven machinery that is reliable, serviceable and having adequate service facility.

\section{Conclusions}

Total cost of seedling for traditional method of planting seedlings per acre was Rs. 1800/- and machine transplanting was Rs. 1000/- per acre. The expenses incurred on plant protection was slightly high in case of conventionally planted fields [Rs. 1500/-], as compared to the mechanically transplanted fields [Rs.1100/-]. Weed management was comparatively lesser [Rs. 3600/-] in case of mechanical transplanted fields, this is mainly because of practicing Cono weeder. But in case of conventionally planted fields weeding expenses reported on Rs. 4000/-. Regarding yield higher in machine transplanted rice $[2350 \mathrm{~kg} / \mathrm{ac}]$ when compared to conventional transplanted rice [2000 $\mathrm{kg} / \mathrm{ac}]$. The benefit-cost ratio was higher in machine transplanted rice $[1: 2.5]$ where is in conventional transplanted rice [1: 1.9]. Hence, the farmers might have more scope to cultivate machine transplanted rice with higher profitability. The constraints faced by the farmers in machine transplantation were no proper training on operation, Non-timely availability of transplanter and land fragmentation. If increase more training to the farmers to operate rice transplanter and government might encourage more hiring centers for rice transplanter might boost up the machine transplanted rice.

\section{References}

Farm Survey, 2018 